\title{
PHYSIOLOGICAL AND BIOCHEMICAL RESPONSES OF (APTENIA CORDIFOLIA) TO SALT STRESS AND ITS REMEDIATIVE EFFECT ON SALINE SOILS
}

\author{
KARAKAS, S. $^{{ }^{*}}$ - DIKILITAS, M. $^{2}-$ ALMACA, A. ${ }^{1}-$ TIPIRDAMAZ, R. ${ }^{3}$ \\ ${ }^{1}$ Department of Soil Science and Plant Nutrition, Faculty of Agriculture, Harran University, \\ Sanliurfa, Turkey \\ ${ }^{2}$ Department of Plant Protection, Faculty of Agriculture, Harran University, Sanliurfa, Turkey \\ ${ }^{3}$ Department of Biology, Faculty of Science, Hacettepe University, Ankara, Turkey \\ *Corresponding author \\ e-mail: skarakas@harran.edu.tr; phone: +90-414-318-3679
}

(Received $9^{\text {th }}$ Sep 2019; accepted 21 $1^{\text {st }}$ Jan 2020)

\begin{abstract}
Salinization is one of the most significant environmental problems in the world. Salinity negatively affects the physicochemical properties of the soil and reduces crop production. This study aimed to investigate the potential use of Aptenia cordifolia $\mathrm{L}$. for the phytoremediation of salt-affected soils. Three salt levels; non-saline (NS, EC: $1.38 \mathrm{dS} \mathrm{m}^{-1}$ ), slightly saline (SS, EC: $3.54 \mathrm{dS} \mathrm{m}^{-1}$ ) and highly saline (HS, EC: $9.58 \mathrm{dS} \mathrm{m}^{-1}$ ) soils were collected from Harran Plain-Turkey and used to cultivated $A$. cordifolia in pots. To assess the salt tolerance of the plants, physiological and biochemical parameters as well as the accumulation of leaf $\mathrm{Na}^{+}$and $\mathrm{Cl}^{-}$ions were determined. In the meantime, soils were evaluated in terms of electrical conductivity, $\mathrm{pH}$, organic matter and soil enzymes (dehydrogenase, urease, phosphatase and protease) before and after the cultivation. A significant increase in shoot fresh weight and dry weight were obtained from A. cordifolia cultivated-SS soils. No significant differences were determined in terms of crop yield in NS and HS soils. A decrease in total chlorophyll content was evident only in plants growing in HS soils. Proline and malondialdehyde contents and the activity of catalase and peroxidase enzymes were found significantly higher $(\mathrm{P} \leq 0.05)$ in plants growing in $\mathrm{HS}$ as compared to those growing in SS and NS soils. A. cordifolia plants, accumulated more $\mathrm{Na}^{+}$and $\mathrm{Cl}^{-}$ions in their leaves as the salinity levels increased. Soil $\mathrm{pH}$ levels under all soil conditions were not affected although slim increases were observed. However, soil electrical conductivity were decreased 2 and 2.5 times in SS and HS soil types, respectively. Soil organic matter were significantly increased along with the increase in the activity of soil enzymes in all soil types. We suggest that cultivation A. cordifolia in SS and HS soils will improve the condition of soil physicochemical properties in an environmentally-friendly manner.
\end{abstract}

Keywords: abiotic stress, phytoremediation, soil enzymes, halophytes, ameliorate

\section{Introduction}

Salinization is a worldwide problem in which salts gradually accumulate in the soil. In this process, water-soluble salts in the soils are dissolved via irrigation or rain and transferred to upper part of the soil and can then be accumulated when irrigation or rain ceased in semi-arid or arid environments (Panta et al., 2018). This negatively affects the crop productivity, quality and microbial community thus affects soil health (FAO, 2016). Due to soil salinization, soil infertility has been in an increasing trend (Slama et al., 2015). If serious measurements have not been taken, salt stress not only negatively affects the physical and chemical properties of the soil but also reduces the concentration of microorganisms and decrease the soil fertility. On the other hand, salinity reduces the quality and quantity of crops and in severe cases, it would not allow any seeds to germinate in which the standing point of agriculture (Yuan et al., 2007; 
Negrao et al., 2017). Salt stress also leads to the production of reactive oxygen species (ROS) in crop plants that disrupt the membrane functionality and damages protein, lipid and nucleic acids. Although plants are able to develop a series of ROS detoxification mechanisms to minimize the impact of ROS via antioxidative enzyme systems including catalase (CAT), glutathione reductase (GR), superoxide dismutase (SOD), ascorbate peroxidase (APX) and non-enzymatic metabolites (ascorbate, proline, glutathione etc.), this may not be enough for plants to function under harsh conditions. Even resistant plants may not cope with the ongoing stress such as salinity and heavy metal stress (Gill and Tuteja, 2010; Hossain et al., 2017).

In nature, plants develop various physiological and biochemical mechanisms in order to survive in soils characterized with salinity. General salt tolerance mechanisms include ion homeostasis and compartmentalization, ion transport and uptake and synthesis of osmoprotectants via compatible solutes (Gupta and Huang, 2014). Halophytes are plants that can tolerate and grow in soils characterized with high salt concentration. They, in general, are known to accumulate salts in various plant parts such as leaf, root etc. (Grigore et al., 2014; Flowers and Colmer).

Various physical, chemical and biological techniques can be used to remediate salt contaminated soils. The use of halophytes is one of the most promising and costeffective methods for phytoremediation. It is a strategy where plants are used to remove, immobilize, degrade the soil contaminants such as salt and heavy metals (Kaushal et al., 2015). Phytoremediation has been used to manage wastes, especially petroleum hydrocarbons, polycyclic aromatic hydrocarbon, organic matter, and nutrients. So far a number of plants have been identified in use of phytoremediation purposes. Reclamation of salt-affected soils could be achieved and crop plants could grow in less stressed soils. Glycophyte plants could be grown together with the halophytes as companion plants in such soils. Also, the harvested above-ground biomass of halophytes can be used as animal feed (Ammari et al., 2013; Karakas et al., 2013).

A. cordifolia (L. f.) Schwant, also known as Mesembryanthemum cordifolium, is a species of succulent plant from the Aizoaceae family and has a Crassulacean acid metabolism (CAM) (Herppich and Peckmann, 1997; Tripodi and Modesta, 2003). In this study, we aimed to determine the performance of $A$. cordifolia against salt stress and to evaluate its performance under saline conditions for phytoremediation purposes. We determined the shoot fresh and dry weight, total chlorophyll, proline, malondialdehyde (MDA), $\mathrm{Na}^{+}$and $\mathrm{Cl}^{-}$ions levels and catalase (CAT, E.C.1.11.1.6) and peroxidase (POX, E.C.1.11.1.7) enzyme responses of $A$. cordifolia. We also elucidated the physical and chemical properties of the soil in the vicinity of root area of $A$. cordifolia to determine the remediation capacity of the halophyte through measurement of soil electrical conductivity (EC), $\mathrm{pH}$, organic matter $(\mathrm{OM})$, ion $\left(\mathrm{Na}^{+}, \mathrm{Cl}^{-}\right)$contents and soil enzyme activities (dehydrogenase, urease and protease) prior to and following cultivation with $A$. cordifolia.

\section{Materials and methods}

\section{Experimental design and plant growth}

Treatments consisted of three different soil salinity levels; non-saline (NS, EC: $1.38 \mathrm{dS} \mathrm{m}^{-1}$ ), slightly saline (SS, EC: $3.54 \mathrm{dS} \mathrm{m}^{-1}$ ) and highly saline (HS, EC: $9.58 \mathrm{dS}$ $\mathrm{m}^{-1}$ ) soils collected from Harran Plain-Turkey. Trials were performed in a randomized block design with three replicates. Before trial, soil samples were carefully air-dried to 
allow sieving with a 2-mm mesh sieve. Three-week-old A. cordifolia seedlings were planted into 8 -L pots containing $6 \mathrm{~kg}$ air-dried soil from each category in greenhouse $\left(35^{\circ} \mathrm{C} \pm 1\right)$ conditions. The seedlings were planted on (April 2016) at a rate of 6 plants per pot. Pots were irrigated with full field capacity. Plants were then harvested on (July 2016) 100 days after onset of treatments. For the plant analysis, the shoot fresh weight (FW) and shoot dry weight (DW) were determined following harvest (Fig. 1).

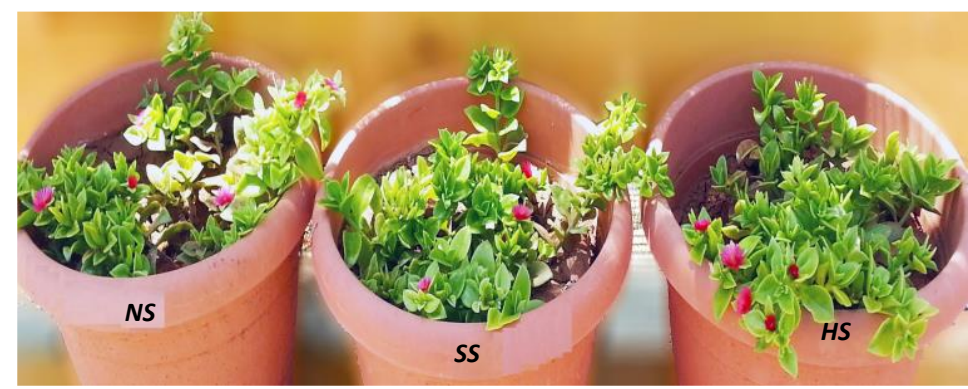

Figure 1. Growth of A. cordifolia at three different salinity levels

Total chlorophyll contents were determined according to the method of Arnon (1949) with slight modifications (Dikilitas, 2003). For the analysis, a $0.5 \mathrm{~g}$ leaf sample was homogenized in a $5 \mathrm{~mL}$ acetone: water $(80: 20 \% \mathrm{v} / \mathrm{v})$ mixture. After filtration through Whatman No. 2 filter paper, a reading was made against $80 \%$ acetone blank for total chlorophyll at $652 \mathrm{~nm}$ using a UV spectrophotometer (UV-1700, Shimadzu). The results were then expressed as $\mathrm{mg} \mathrm{g}^{-1} \mathrm{FW}$ for total chlorophyll.

The proline measurement was conducted according to the method of Bates et al. (1973). Acid-ninhydrin was employed as a reagent, which was made by dissolving (warming and agitating) $1.25 \mathrm{~g}$ of ninhydrin in $30 \mathrm{~mL}$ of glacial acetic acid and $20 \mathrm{~mL}$ of $6 \mathrm{M}$ phosphoric acid. A quantity of $0.5 \mathrm{~g}$ of leaf material was homogenized in $10 \mathrm{~mL}$ of $3 \% \mathrm{w} / \mathrm{v}$ sulphosalicylic acid then the homogenate was filtered through Whatman No. 2 filter paper. A 2-mL of filtrate was mixed in a test tube with $2 \mathrm{~mL}$ of acid ninhydrin reagent and boiled at $100{ }^{\circ} \mathrm{C}$ for $1 \mathrm{~h}$. The reaction was terminated in an ice bath. The reaction mixture was extracted with $5 \mathrm{~mL}$ of toluene. Tubes were thoroughly shaken for 15-20 s and left for further $20 \mathrm{~min}$ in order to achieve separation of the two layers. The chromophore containing toluene was removed and allowed to warm to room temperature. Absorbance of the solution was measured at $515 \mathrm{~nm}$ using a toluene blank as a reference in a spectrophotometry (UV-1700, Shimadzu). The results were expressed as $\mu \mathrm{mol} \mathrm{g}^{-1}$ fresh tissue.

The malondialdehyde (MDA) content was determined according to the method of Sairam and Sexena (2003). A $0.5 \mathrm{~g}$ leaf tissue sample was homogenized using $10 \mathrm{~mL}$ of a $0.1 \%$ trichloroacetic acid (TCA) and the homogenate was centrifuged at 10,000 $\mathrm{g}$ for $5 \mathrm{~min}$. Four $\mathrm{mL}$ of $20 \% \mathrm{v} / \mathrm{v}$ TCA containing $0.5 \% \mathrm{v} / \mathrm{v}$ thiobarbituric acid (TBA) was added to $1 \mathrm{~mL}$ of the supernatant. The solution was heated at $95{ }^{\circ} \mathrm{C}$ for $30 \mathrm{~min}$ and then quickly cooled on ice. The mixture was centrifuged once again at 10,000 $\mathrm{g}$ for $5 \mathrm{~min}$ and the absorbance of the clean supernatant was determined at 532 and $600 \mathrm{~nm}$. The MDA content was calculated using Equation 1.

$$
\operatorname{MDA}\left(\text { nmol g }^{-1}\right)=\frac{\text { Extract volume }(\mathrm{ml}) \times\left[\left(A_{532}-A_{600}\right) /\left(155 \mathrm{mM}^{-1} \mathrm{~cm}^{-1}\right)\right]}{\text { Sample amaunt }(\mathrm{g})} \times 10^{3}(\mathrm{Eq} .1)
$$


Catalase enzyme activity (CAT, E.C.1.11.1.6) was determined by monitoring the decomposition of $\mathrm{H}_{2} \mathrm{O}_{2}$ according to the method of Aebi (1984), with slight modifications (Karakas et al., 2016). For the analysis, $0.5 \mathrm{~g}$ of plant material was homogenized in $10 \mathrm{~mL}$ of a $50 \mathrm{mM} \mathrm{Na}$-phosphate buffer solution then $50 \mu \mathrm{L}$ of plant extract was added to a $2.95 \mathrm{~mL}\left(10 \mathrm{mM} \mathrm{H}_{2} \mathrm{O}_{2}, 50 \mathrm{mM}\right.$ Na-phosphate buffer and $4 \mathrm{mM}$ $\mathrm{Na}_{2}$ EDTA) reaction mixture and measured for $30 \mathrm{~s}$ at $240 \mathrm{~nm}$ with a UV spectrometer (UV-1700, Shimadzu). One CAT activity unit (U) is defined as a change of 0.1 absorbance unit per minute. Activity is expressed as enzyme units per gram fresh weight.

Peroxidase enzyme activity (POX, E.C.1.11.1.7) was determined by monitoring the increase in absorbance due to the tetraguaiacol formation at $470 \mathrm{~nm}$ according to the method of Cvikrova et al. (1994) with slight modifications (Karakas et al., 2016). For the analysis, $100 \mu \mathrm{L}$ of extract (obtained as above) was added to $3 \mathrm{~mL}$ of the reaction mixture (13 $\mathrm{mM}$ guaiacol, $5 \mathrm{mM} \mathrm{H} \mathrm{O}_{2}$, and $50 \mathrm{mM}$ Na-phosphate, $\mathrm{pH}$ 6.5). The reaction was initiated with an $\mathrm{H}_{2} \mathrm{O}_{2}$ addition and was measured at $470 \mathrm{~nm}$ using a UV spectrophotometer (UV-1700, Shimadzu) at 1-min interval until $3^{\text {rd }}$ minute. One unit of POX activity is defined as a change of 0.1 absorbance unit per minute at $470 \mathrm{~nm}$. Activity is expressed as enzyme units per gram of fresh weight.

The $\mathrm{Na}^{+}$ion content of leaves was determined according to the method of Chapman and Pratt (1961). with slight modifications (Karakas et al., 2016). Samples burned at $500{ }^{\circ} \mathrm{C}$ were homogenized in $5 \mathrm{~mL}$ of a $2 \mathrm{~N} \mathrm{HCl}$. For quantification of $\mathrm{Na}^{+}$ions, the homogenate obtained following filtration was analyzed via Inductively Coupled Plasma (ICP, Perkin Elmer).

Chloride determination of plant samples was made according to the Mohr method using indicator (Johnson and Ulrich, 1959; Kacar and Inal, 2008).

Soil samples electrical conductivity $(\mathrm{EC}), \mathrm{pH}$, organic matter $(\mathrm{OM})$ content and soil enzymes were determined before and after the trial. Soil EC and $\mathrm{pH}$ were determined using a saturated soil paste extraction (Soil Conservation Service, 1972; Thomas, 1996). OM content was determined according to Walkley (1947) and FAO (1974). One gram soil, $10 \mathrm{~mL} 1 \mathrm{~N} \mathrm{Cr}_{2} \mathrm{O}_{7}^{-}$solution and $20 \mathrm{~mL}$ concentrated $\mathrm{H}_{2} \mathrm{SO}_{4}$ were poured into $500 \mathrm{~mL}$ beaker and mixed and allowed to stand for $30 \mathrm{~min}$ at room temperature. Then,

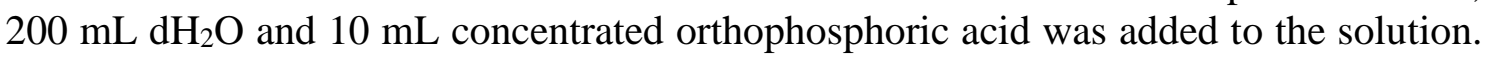
The mixture was then cooled down to room temperature and 10-15 drops of diphenylamine indicator were added. The mixture was then titrated with $0.5 \mathrm{M}$ $\mathrm{FeH}_{8} \mathrm{~N}_{2} \mathrm{O}_{8} \mathrm{~S}_{2}$ solution until the color changes from violet-blue to green. A reagent blank using the above procedure without soil was employed. The blank is used to standardize the $\mathrm{Fe}^{2+}$ solution daily. OM was calculated with Equation 2.

$$
\text { Total } C(\%)=\left((A-S) x F e^{+2} x(0.003) x(100 / B)\right)
$$

To convert total $\mathrm{C}$, the results were multiplied by 1.30 into the correction factor, OM, Equation 3 was used.

$$
O M(\%)=\text { TotalCx } 1.72 / 0.58
$$

where A: blank titration $\mathrm{ml}$ ferrous solution, B: sample titration $\mathrm{ml}$ ferrous solution, 0.003: milliequivalent weight of $\mathrm{C}$ in $\mathrm{g}$, factor of 1.72 . 
Dehydrogenase activity was measured using triphenyl tetrazolium chloride (TTC) colorimetric analysis according to Tabatabai (1994). The principle of dehydrogenase assay is that when metabolizing cells come in contact with an aqueous solution of 2,3,5triphenyl tetrazolium chloride (TTC) under anaerobic conditions, it is converted into triphenylformazan (TPF) and can be measured colorimetrically. Soil sample $(5 \mathrm{~g})$ was taken in $70 \times 150 \mathrm{~mm}$ screw cap tubes. To each tube, $1 \mathrm{ml}$ of $3 \%$ TTC and $5 \mathrm{ml}$ of deionized water were added. Then the samples were mixed on a vortex, the tubes were stoppered and incubated in the dark for $24 \mathrm{~h}$ at $37{ }^{\circ} \mathrm{C}$. After incubation, $10 \mathrm{ml}$ of methanol were added, the samples were shaken and and filtered Whatman filter paper No.1. After filtration, the optical reading was made at $485 \mathrm{~nm}$ with a UV spectrophotometer using methanol extract as the blank. The results were expressed as $\mu \mathrm{mol}$ TPF $\mathrm{g}^{-1}$ soil $^{-1}$.

The urease activity was determined following the method of Guan (1986) with some modifications. Briefly, $0.5 \mathrm{ml}$ toluene, $20 \mathrm{ml}$ of $0.1 \mathrm{M} \mathrm{Na}$-citrate buffer ( $\mathrm{pH} \mathrm{6.7)}$ ) and $10 \mathrm{ml}$ of $10 \%$ urea were added to $5.0 \mathrm{~g}$ soil and then the mixture was incubated at

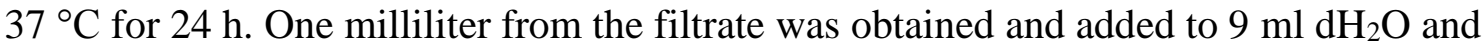
mixed with $4 \mathrm{ml} \mathrm{Na-phenolate} \mathrm{and} 3 \mathrm{ml} \mathrm{NaClO}$. The releasing ammonium was measured with a UV spectrophotometer at $578 \mathrm{~nm}$. A control without urea was prepared with each sample. The results were expressed as mg urease- $\mathrm{N} \mathrm{kg}^{-1} \mathrm{~h}^{-1}$.

Phosphatase activities were measured based on the colorimetric estimation of the $p$ nitrophenol release from $p$-nitrophenyl phosphate (Tabatabai, 1994). One gram soil was placed in a $50-\mathrm{mL}$ Erlenmeyer flask and then $0.2 \mathrm{~mL}$ toluene, $0.1 \mathrm{M}$ modified universal buffer (pH 6.5), $1 \mathrm{ml} \mathrm{0.1} \mathrm{M} \mathrm{p-nitrophenyl} \mathrm{phosphate} \mathrm{(PNP)} \mathrm{solution} \mathrm{was} \mathrm{added} \mathrm{to} \mathrm{the}$ flask. The flask was swirled for a few seconds and incubated at $37^{\circ} \mathrm{C}$ for $1 \mathrm{~h}$ in the incubator with a stopper. After removing the stopper, $1 \mathrm{ml}$ of $0.5 \mathrm{M} \mathrm{CaCl}_{2}$ and $4 \mathrm{ml}$ of $0.5 \mathrm{M} \mathrm{NaOH}$ were added to the mixture. The soil suspension was filtered through Whatman No. 1 filter paper. The optical density of the filtrate was then measured at $420 \mathrm{~nm}$ in a spectrophotometer (UV-1700, Shimadzu). Blank was maintained similarly without soil. The results were expressed as mg $P$-nitrophenyl $\mathrm{kg}^{-1} \mathrm{~h}^{-1}$.

Protease activity was determined according to the method of Girard and Michaud (2002). Air-dried soil $(0.1 \mathrm{~g})$ was placed into $1.5 \mathrm{~mL}$ Eppendorf tube and then $500 \mu \mathrm{L}$ of $1 \%(\mathrm{w} / \mathrm{v})$ azocasein in $50 \mathrm{mmol} \mathrm{L} \mathrm{L}^{-1}$ Tris- $\mathrm{HCl}, \mathrm{pH} 8.8$. Azocasein hydrolysis was initiated by incubating the tubes $2 \mathrm{~h}$ at room temperature. Proteolysis was stopped by adding $300 \mu \mathrm{l}$ of $10(\mathrm{w} / \mathrm{v})$ cold trichloroacetic acid (TCA). After centrifugation for $10 \mathrm{~min}$ at $15000 \mathrm{~g}, 350 \mu \mathrm{l}$ of the supernatant was collected and mixed with of $300 \mu 1$ of $1 \mathrm{~N} \mathrm{NaOH}$. Protease activity was then determined by reading the optical density of the resulting solution at $440 \mathrm{~nm}$ using a UV spectrophotometer. A change of 0.01 units per minute in absorbance was considered to be equal to one unit protease activity, which was expressed as $\mathrm{U}$ (unit) $\mathrm{mg}^{-1}$ protein.

Data were subjected to an analysis of variance (ANOVA) at a significance level of $\mathrm{P} \leq 0.05$ using Duncan's Multiple Range Test (DMRT) from the SPSS software program (Version 22.0). Data are presented as a mean value \pm the standard error.

\section{Results}

\section{Plant analysis of A. cordifolia under salinity levels}

A. cordifolia plants were harvested after 100 days of cultivation from the soils differing in salinity levels. Growth of shoots was followed by measuring FW and DW 
of the plants. At SS soil conditions, FW and DW of the plants significantly increased. At HS soil conditions, FW and DW of the plants did not significantly differ from those of control plants cultivated in NS soil conditions (Fig. $2 A$ and B; Table 1).

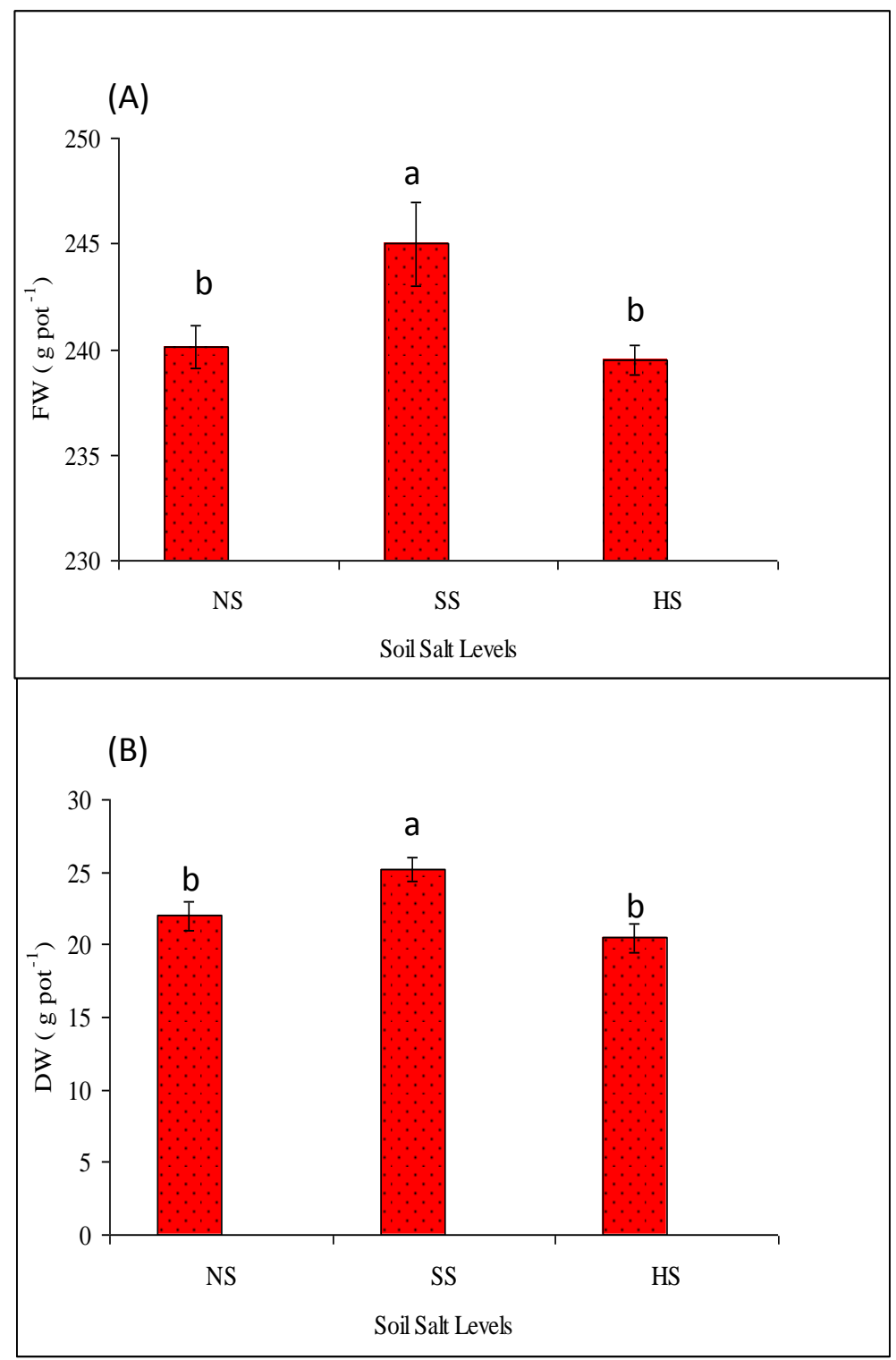

Figure 2. A) $F W, B) D W$ of A. cordifolia plants at three different salinity levels: non-saline (NS), slightly saline (SS), and highly saline (HS) soils. Bars indicate the means of the three replicates \pm standard error. Bars with different letters indicate significant differences from one another according to Duncan's Multiple Range Test at $P \leq 0.05$

When salinity levels increased, the accumulation of $\mathrm{NaCl}$ ions, $\mathrm{Na}^{+}$and $\mathrm{Cl}^{-}$, in leaves of A. cordifolia also increased. The accumulation of both ions was more prominent of HS soil conditions. A. cordifolia plants accumulated approximately $16 \mathrm{~g} \mathrm{Na}^{+}$and $19 \mathrm{~g}$ $\mathrm{Cl}^{-}$ions per $\mathrm{kg}$ leaf at SS soil conditions. On the other hand, A. cordifolia plants at HS soils accumulated almost $28 \mathrm{~g} \mathrm{~kg}^{-1}$ and $32 \mathrm{~g} \mathrm{~kg}^{-1} \mathrm{Na}^{+}$and $\mathrm{Cl}^{-}$ions, respectively their leaves (Fig. 3A and B; Table 1). 


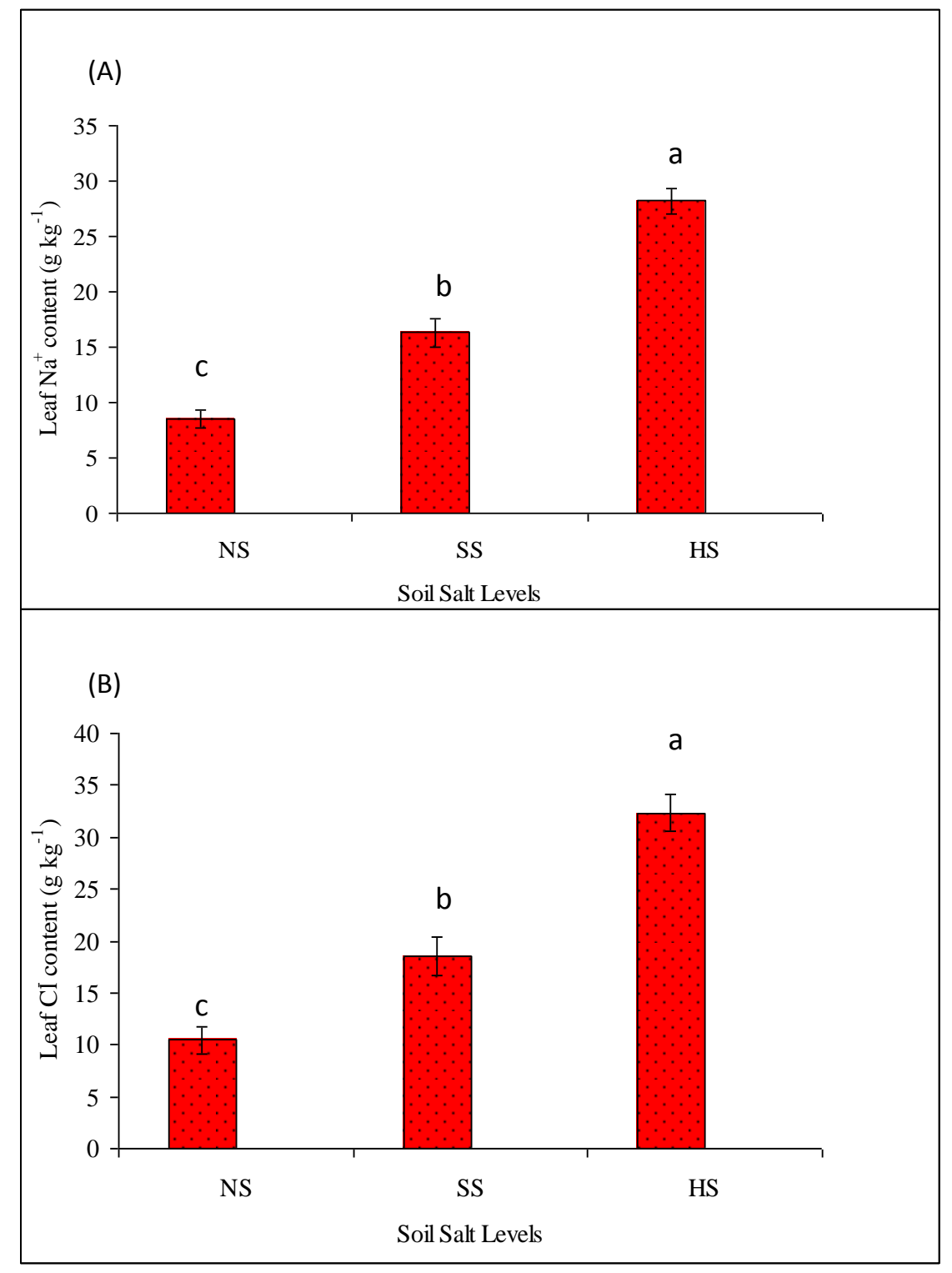

Figure 3. A) leaf $\mathrm{Na}^{+}$content, B) leaf $\mathrm{Cl}^{-}$content of $\mathrm{A}$. cordifolia plants at three different salinity levels: non-saline (NS), slightly saline (SS), and highly saline (HS) soils. Bars indicate the means of the three replicates \pm standard error. Bars with different letters indicate significant differences from one another according to Duncan's Multiple Range Test at $P \leq 0.05$

When biochemical parameters were examined under saline conditions, total chlorophyll contents were not statistically significant at all saline conditions (Fig. 3A). Both proline and MDA contents increased in plants subjected to HS soil conditions. The proline content was $1.9 \mu \mathrm{mol} \mathrm{g}^{-1}$ at HS conditions doubling the levels of NS and SS soil conditions. Again, MDA contents were at the highest levels at HS conditions (Fig. 4B and $C$ ).

As a response to salinity stress, both enzymes, POX and CAT, showed increasing trend as the concentration of $\mathrm{NaCl}$ increased in the soil. A significant increase was evident at HS soil conditions A. cordifolia plants did not exhibit significant enzyme responses at SS soil conditions (Fig. 4D and E; Table 1). 
Table 1. Analyses of plant parameters using ANOVA

\begin{tabular}{|c|c|c|c|c|c|}
\hline Plant parameters & Soil salt levels & $\mathbf{n}$ & Mean \pm S.E & $\mathbf{F}$ & $\mathbf{P}$ \\
\hline \multirow{4}{*}{ FW } & NS & 3 & $240.12 \pm 1.15$ & \multirow{4}{*}{9.07} & \multirow{4}{*}{0.02} \\
\hline & SS & 3 & $245.11 \pm 2.01$ & & \\
\hline & HS & 3 & $239.43 \pm 0.61$ & & \\
\hline & Total & 9 & $241.55 \pm 1.37$ & & \\
\hline \multirow{4}{*}{ DW } & NS & 3 & $21.99 \pm 0.97$ & \multirow{4}{*}{5.69} & \multirow{4}{*}{0.04} \\
\hline & SS & 3 & $25.19 \pm 0.87$ & & \\
\hline & HS & 3 & $20.85 \pm 0.98$ & & \\
\hline & Total & 9 & $22.68 \pm 0.80$ & & \\
\hline \multirow{4}{*}{ Leaf $\mathrm{Na}^{+}$} & NS & 3 & $8.47 \pm 0.55$ & \multirow{4}{*}{86.20} & \multirow{4}{*}{0.00} \\
\hline & SS & 3 & $16.33 \pm 1.23$ & & \\
\hline & HS & 3 & $28.20 \pm 1.27$ & & \\
\hline & Total & 9 & $17.67 \pm 2.92$ & & \\
\hline \multirow{4}{*}{ Leaf $\mathrm{Cl}^{-}$} & NS & 3 & $10.47 \pm 1.35$ & \multirow{4}{*}{41.41} & \multirow{4}{*}{0.00} \\
\hline & SS & 3 & $18.54 \pm 1.98$ & & \\
\hline & HS & 3 & $32.35 \pm 1.77$ & & \\
\hline & Total & 9 & $20.46 \pm 3.31$ & & \\
\hline \multirow{4}{*}{ Total chlorophyll } & NS & 3 & $1.51 \pm 0.29$ & \multirow{4}{*}{0.05} & \multirow{4}{*}{0.95} \\
\hline & SS & 3 & $1.46 \pm 0.14$ & & \\
\hline & HS & 3 & $1.41 \pm 0.28$ & & \\
\hline & Total & 9 & $1.46 \pm 0.12$ & & \\
\hline \multirow{4}{*}{ Proline } & NS & 3 & $0.96 \pm 0.07$ & \multirow{4}{*}{48.87} & \multirow{4}{*}{0.00} \\
\hline & SS & 3 & $1.07 \pm 0.09$ & & \\
\hline & HS & 3 & $1.91 \pm 0.06$ & & \\
\hline & Total & 9 & 1.310 .15 & & \\
\hline \multirow{4}{*}{ MDA } & NS & 3 & $1.40 \pm 0.21$ & \multirow{4}{*}{49.40} & \multirow{4}{*}{0.00} \\
\hline & SS & 3 & $1.71 \pm 0.29$ & & \\
\hline & HS & 3 & $5.25 \pm 0.38$ & & \\
\hline & Total & 9 & $2.79 \pm 0.64$ & & \\
\hline \multirow{4}{*}{ CAT } & NS & 3 & $0.43 \pm 0.08$ & \multirow{4}{*}{6.09} & \multirow{4}{*}{0.04} \\
\hline & SS & 3 & $0.52 \pm 0.10$ & & \\
\hline & HS & 3 & $0.96 \pm 0.16$ & & \\
\hline & Total & 9 & $0.64 \pm 0.10$ & & \\
\hline \multirow{4}{*}{ POX } & NS & 3 & $2.41 \pm 0.23$ & \multirow{4}{*}{26.31} & \multirow{4}{*}{0.00} \\
\hline & SS & 3 & $2.72 \pm 0.25$ & & \\
\hline & HS & 3 & $6.28 \pm 0.64$ & & \\
\hline & Total & 9 & $3.80 \pm 0.65$ & & \\
\hline
\end{tabular}

\section{Soil analysis of A. cordifolia under salinity levels}

Soil characteristics such as soil $\mathrm{pH}, \mathrm{EC}$ and $\mathrm{OM}$ contents were evaluated bare soil before (control) and after cultivation with A. cordifolia. To make a comprehensive evaluation, bare soil (not cultivated with any plants) was also employed when $\mathrm{pH}, \mathrm{EC}$ and $\mathrm{OM}$ contents were measured. In this trial, physical soil parameters were determined and recorded in all soil conditions before and after 100-days cultivation with $A$. 
cordifolia. The same parameters were-remeasured to see the differences in measured soil parameters. According to our findings, soil $\mathrm{pH}$ levels measured at different salinity conditions did not change throughout the course of the experiment. Cultivation of saline soils with A. cordifolia plants increased soil $\mathrm{pH}$ levels, however, this was not significant as compared to those of soils with no-cultivation (Fig. 5A; Table 2).

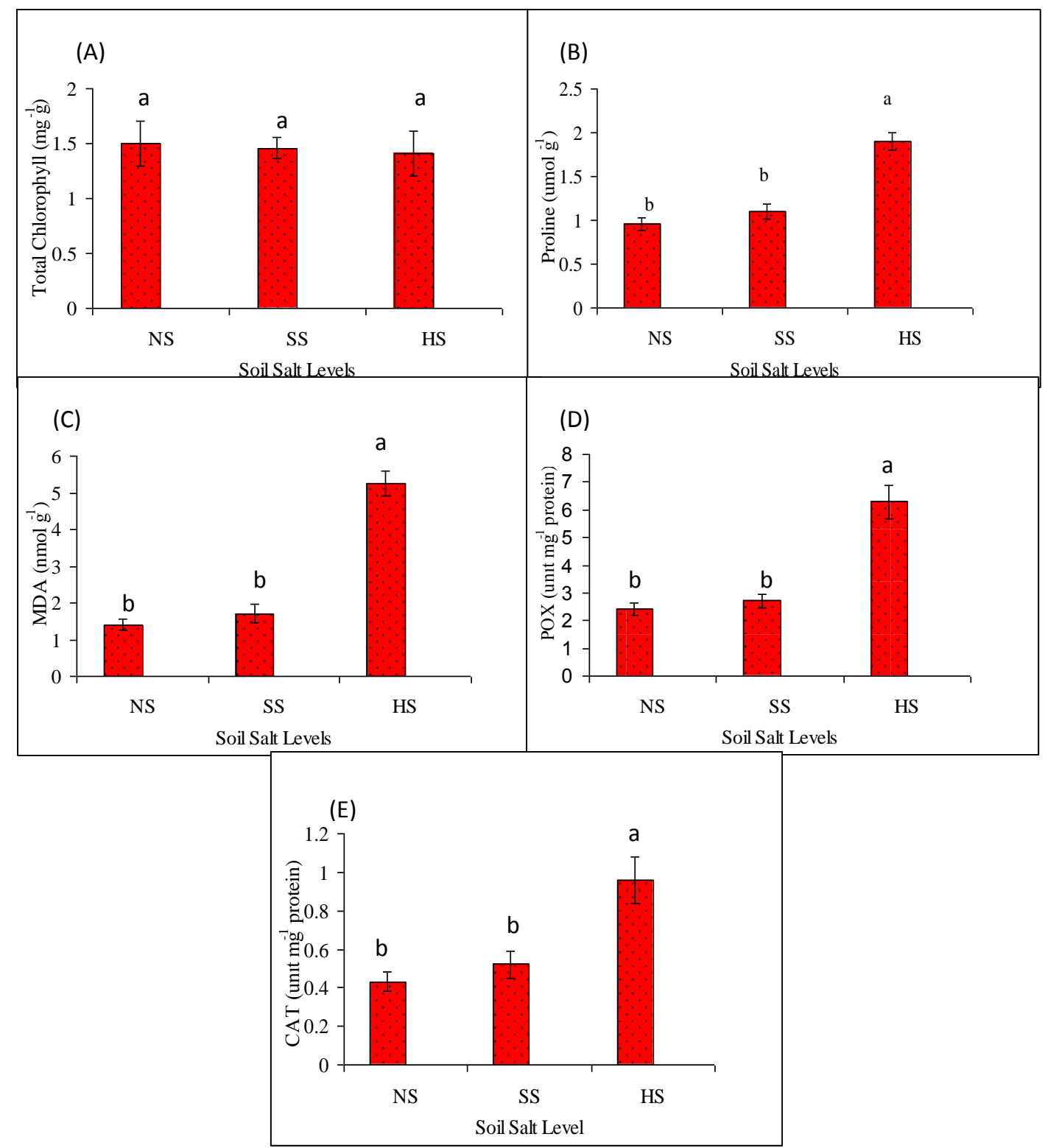

Figure 4. A) Total chlorophyll; B) proline; C) MDA; D) POX and E) CAT of A. cordifolia plants at three different salinity levels: non-saline (NS), slightly saline (SS), and highly saline (HS) soils. Bars indicate the means of the three replicates \pm standard error. Bars with different letters indicate significant differences from one another according to Duncan's Multiple Range Test at $P \leq 0.05$

Use of $A$. cordifolia also affected the contents of $\mathrm{OM}$ in all soil conditions including SS soil conditions. Cultivation with $A$. cordifolia improved the soil OM significantly 
meaning that cultivation with $A$. cordifolia contributed soil OM by secreting organic materials from their root systems (Fig. 5B; Table 2).

When soil EC levels were measured, it was determined that soil EC levels were significantly decreased in all conditions after 100-days cultivation with A. cordifolia (Fig. 5C; Table 2). Decrease in soil EC level was more remarkable in HS soil conditions.

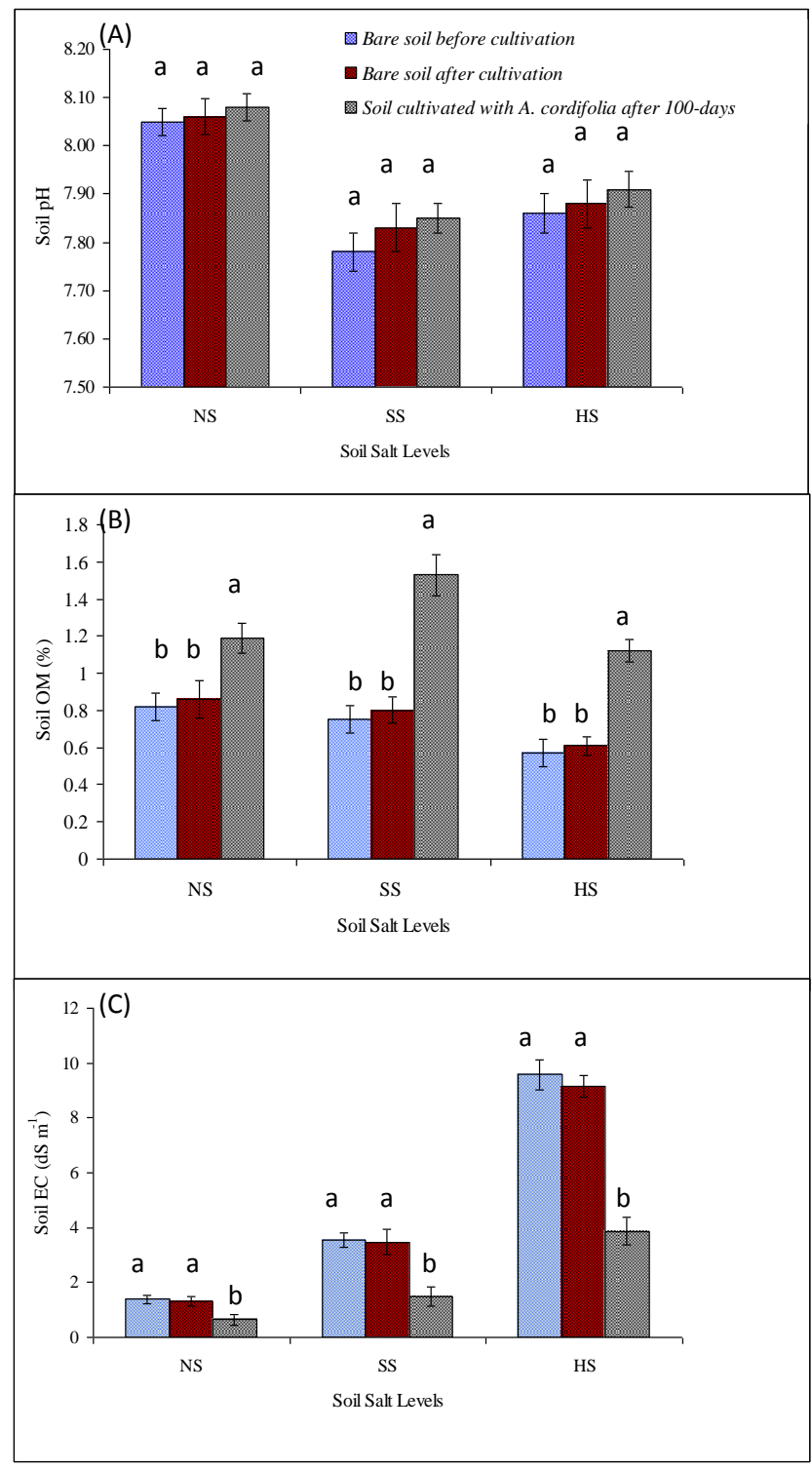

Figure 5. A) soil $p H$; B) soil OM; C) soil EC values of before and after cultivation with A. cordifolia at three different salinity levels: non-saline (NS), slightly saline (SS), and highly saline $(H S)$ soils. Bars with different letters indicate significant differences from one another according to Duncan's Multiple Range Test at $P \leq 0.05$

Finally, soil enzymes were measured in all soil conditions to see if A. cordifolia plants contributed to soil health through increase in soil enzymes. Accordingly, cultivation with $A$. cordifolia significantly increased the soil enzymes such as dehydrogenase, urease, phosphatase and protease. 
Table 2. Analyses of soil characteristics ( $p H, E C$ and OM) using ANOVA before and after cultivation with A. cordifolia

\begin{tabular}{|c|c|c|c|c|c|c|c|c|c|c|c|c|c|}
\hline \multirow{2}{*}{$\begin{array}{l}\text { Soil salt } \\
\text { levels }\end{array}$} & \multirow{2}{*}{ Application } & \multicolumn{4}{|c|}{ pH } & \multicolumn{4}{|c|}{ OM } & \multicolumn{4}{|c|}{ EC } \\
\hline & & $\mathbf{n}$ & Mean \pm S.E & $\mathbf{F}$ & $\mathbf{P}$ & $\mathbf{n}$ & Mean \pm S.E & $\mathbf{F}$ & $\mathbf{P}$ & $\mathbf{n}$ & Mean \pm S.E & $\mathbf{F}$ & $\mathbf{P}$ \\
\hline \multirow{4}{*}{ NS } & Bare soil before cultivated & 3 & $8.05 \pm 0.03$ & \multirow{4}{*}{0.24} & \multirow{4}{*}{0.80} & 3 & $0.82 \pm 0.07$ & \multirow{4}{*}{5.76} & \multirow{4}{*}{$0.04^{*}$} & 3 & $1.38 \pm 0.15$ & \multirow{4}{*}{6.82} & \multirow{4}{*}{0.02} \\
\hline & Bare soil after cultivated & 3 & $8.06 \pm 0.04$ & & & 3 & $0.87 \pm 0.10$ & & & 3 & $1.34 \pm 0.21$ & & \\
\hline & $\begin{array}{l}\text { Soil cultivated with } A \text {. } \\
\text { cordifolia after } 100 \text { days }\end{array}$ & 3 & $8.08 \pm 0.03$ & & & 3 & $1.19 \pm 0.08$ & & & 3 & $0.65 \pm 0.13$ & & \\
\hline & Total & 9 & $8.06 \pm 0.02$ & & & 9 & $0.96 \pm 0.07$ & & & 9 & $1.12 \pm 0.13$ & & \\
\hline \multirow{4}{*}{ SS } & Bare soil before cultivated & 3 & $7.78 \pm 0.05$ & \multirow{4}{*}{0.58} & \multirow{4}{*}{0.59} & 3 & $0.75 \pm 0.10$ & \multirow{4}{*}{16.43} & \multirow{4}{*}{$0.00^{* *}$} & 3 & $3.54 \pm 0.35$ & \multirow{4}{*}{7.29} & \multirow{4}{*}{0.03} \\
\hline & Bare soil after cultivated & 3 & $7.83 \pm 0.06$ & & & 3 & $0.80 \pm 0.08$ & & & 3 & $3.46 \pm 0.53$ & & \\
\hline & $\begin{array}{l}\text { Soil cultivated with } A \text {. } \\
\text { cordifolia after } 100 \text { days }\end{array}$ & 3 & $7.85 \pm 0.03$ & & & 3 & $1.53 \pm 0.14$ & & & 3 & $1.48 \pm 0.40$ & & \\
\hline & Total & 9 & $7.82 \pm 0.03$ & & & 9 & $1.03 \pm 0.14$ & & & 9 & $2.83 \pm 0.40$ & & \\
\hline \multirow{4}{*}{ HS } & Bare soil before cultivated & 3 & $7.86 \pm 0.04$ & \multirow{4}{*}{0.31} & \multirow{4}{*}{0.74} & 3 & $0.57 \pm 0.15$ & & & 3 & $9.58 \pm 0.64$ & \multirow{4}{*}{34.41} & \multirow{4}{*}{0.00} \\
\hline & Bare soil after cultivated & 3 & $7.88 \pm 0.05$ & & & 3 & $0.61 \pm 0.06$ & & & 3 & $9.14 \pm 0.47$ & & \\
\hline & $\begin{array}{l}\text { Soil cultivated with } A \text {. } \\
\text { cordifolia after } 100 \text { days }\end{array}$ & 3 & $7.91 \pm 0.04$ & & & 3 & $1.13 \pm 0.05$ & 9.88 & $0.01^{* *}$ & 3 & $3.87 \pm 0.49$ & & \\
\hline & Total & 9 & $7.88 \pm 0.02$ & & & 9 & $0.77 \pm 0.10$ & & & 9 & $7.53 \pm 0.96$ & & \\
\hline
\end{tabular}

A. cordifolia plants contributed to soil enzyme activities in NS soil conditions an indicating that soil health could be improved via cultivation with this plant (Figs. 6A, B, $C$ and $D$; Table 3). Also, A. cordifolia plants improved soil enzyme levels in saline conditions. For example, soil dehydrogenase activity 1.5, soil urease activity 1.4, soil phosphatase activity 1.2 and soil protease activity 1.8 times increased after cultivation with A. cordifolia plants in HS soil conditions when compared to control soil (bare soil before cultivated). The increase in soil enzyme levels were more prominent in SS and HS soil conditions indicating that $A$. cordifolia plants played significant roles under saline stress conditions.

Table 3. Analyses of soil enzymes (dehydrogenase, urease, phosphatase, and protease) using ANOVA before and after cultivation with A. cordifolia

\begin{tabular}{|c|c|c|c|c|c|c|c|c|c|c|c|c|c|c|c|c|c|}
\hline \multirow{2}{*}{$\begin{array}{l}\text { Soil } \\
\text { salt } \\
\text { levels }\end{array}$} & \multirow{2}{*}{ Application } & \multicolumn{4}{|c|}{ Dehydrogenase } & \multicolumn{4}{|c|}{ Urease } & \multicolumn{4}{|c|}{ Phosphatase } & \multicolumn{4}{|c|}{ Protease } \\
\hline & & $\mathbf{n}$ & Mean \pm S.E. & $\mathbf{F}$ & $\mathbf{P}$ & $\mathbf{n}$ & Mean \pm S.E. & $\mathbf{F}$ & $\mathbf{P}$ & n & Mean \pm S.E. & $\mathbf{F}$ & $\mathbf{P}$ & $\mathbf{n}$ & Mean \pm S.E. & $\mathbf{F}$ & $\mathbf{P}$ \\
\hline \multirow{4}{*}{ NS } & Bare soil before cultivated & 3 & $19.10 \pm 1.58$ & \multirow{4}{*}{7.50} & \multirow{4}{*}{0.02} & 3 & $67.67 \pm 0.88$ & \multirow{4}{*}{11.45} & \multirow{4}{*}{0.01} & 3 & $142.33 \pm 5.04$ & \multirow{4}{*}{20.58} & \multirow{4}{*}{0.00} & 3 & $37.60 \pm 3.75$ & \multirow{4}{*}{5.03} & \multirow{4}{*}{0.0} \\
\hline & Bare soil after cultivated & 3 & $20.10 \pm 1.58$ & & & 3 & $69.33 \pm 1.45$ & & & 3 & $150.00 \pm 5.29$ & & & 3 & $40.17 \pm 0.73$ & & \\
\hline & $\begin{array}{l}\text { Soil cultivated with } A \text {. } \\
\text { cordifolia after } 100 \text { days }\end{array}$ & 3 & $25.95 \pm 0.69$ & & & 3 & $78.10 \pm 2.31$ & & & 3 & $180.00 \pm 2.08$ & & & 3 & $48.50 \pm 2.18$ & & \\
\hline & Total & 9 & $21.72 \pm 1.26$ & & & 9 & $71.70 \pm 1.82$ & & & 9 & $157.44 \pm 6.15$ & & & 9 & $42.09 \pm 2.08$ & & \\
\hline \multirow{4}{*}{ SS } & Bare soil before cultivated & 3 & $11.23 \pm 1.40$ & \multirow{4}{*}{17.70} & \multirow{4}{*}{0.00} & 3 & $54.73 \pm 1.97$ & \multirow{4}{*}{6.35} & \multirow{4}{*}{0.03} & 3 & $110.33 \pm 3.76$ & \multirow{4}{*}{24.35} & \multirow{4}{*}{0.00} & 3 & $26.10 \pm 2.74$ & \multirow{4}{*}{10.79} & \multirow{4}{*}{0.01} \\
\hline & Bare soil after cultivated & 3 & $12.20 \pm 1.01$ & & & 3 & $58.46 \pm 1.13$ & & & 3 & $120.00 \pm 7.64$ & & & 3 & $27.00 \pm 3.28$ & & \\
\hline & $\begin{array}{l}\text { Soil cultivated with } A \text {. } \\
\text { cordifolia after } 100 \text { days }\end{array}$ & 3 & $19.28 \pm 0.55$ & & & 3 & $69.17 \pm 4.62$ & & & 3 & $160.00 \pm 3.61$ & & & 3 & $46.57 \pm 4.35$ & & \\
\hline & Total & 9 & $14.24 \pm 1.37$ & & & 9 & $60.79 \pm 2.62$ & & & 9 & $130.11 \pm 8.06$ & & & 9 & $33.22 \pm 3.77$ & & \\
\hline \multirow{4}{*}{ HS } & Bare soil before cultivated & 3 & $4.28 \pm 0.19$ & \multirow{4}{*}{9.25} & \multirow{4}{*}{0.02} & 3 & $51.20 \pm 1.61$ & \multirow{4}{*}{10.99} & \multirow{4}{*}{0.01} & 3 & $81.00 \pm 5.13$ & \multirow{4}{*}{6.54} & \multirow{4}{*}{0.03} & 3 & $21.50 \pm 1.59$ & \multirow{4}{*}{7.06} & \multirow{4}{*}{0.03} \\
\hline & Bare soil after cultivated & 3 & $4.07 \pm 0.37$ & & & 3 & $50.46 \pm 1.96$ & & & 3 & $85.00 \pm 2.89$ & & & 3 & $23.29 \pm 1.09$ & & \\
\hline & $\begin{array}{c}\text { Soil cultivated with } A \text {. } \\
\text { cordifolia after } 100 \text { days }\end{array}$ & 3 & $6.31 \pm 0.57$ & & & 3 & $68.90 \pm 2.27$ & & & 3 & $102.00 \pm 4.73$ & & & 3 & $37.54 \pm 2.46$ & & \\
\hline & Total & 9 & $4.89 \pm 0.65$ & & & 9 & $56.89 \pm 2.12$ & & & 9 & $89.33 \pm 3.89$ & & & 9 & $27.44 \pm 1.65$ & & \\
\hline
\end{tabular}




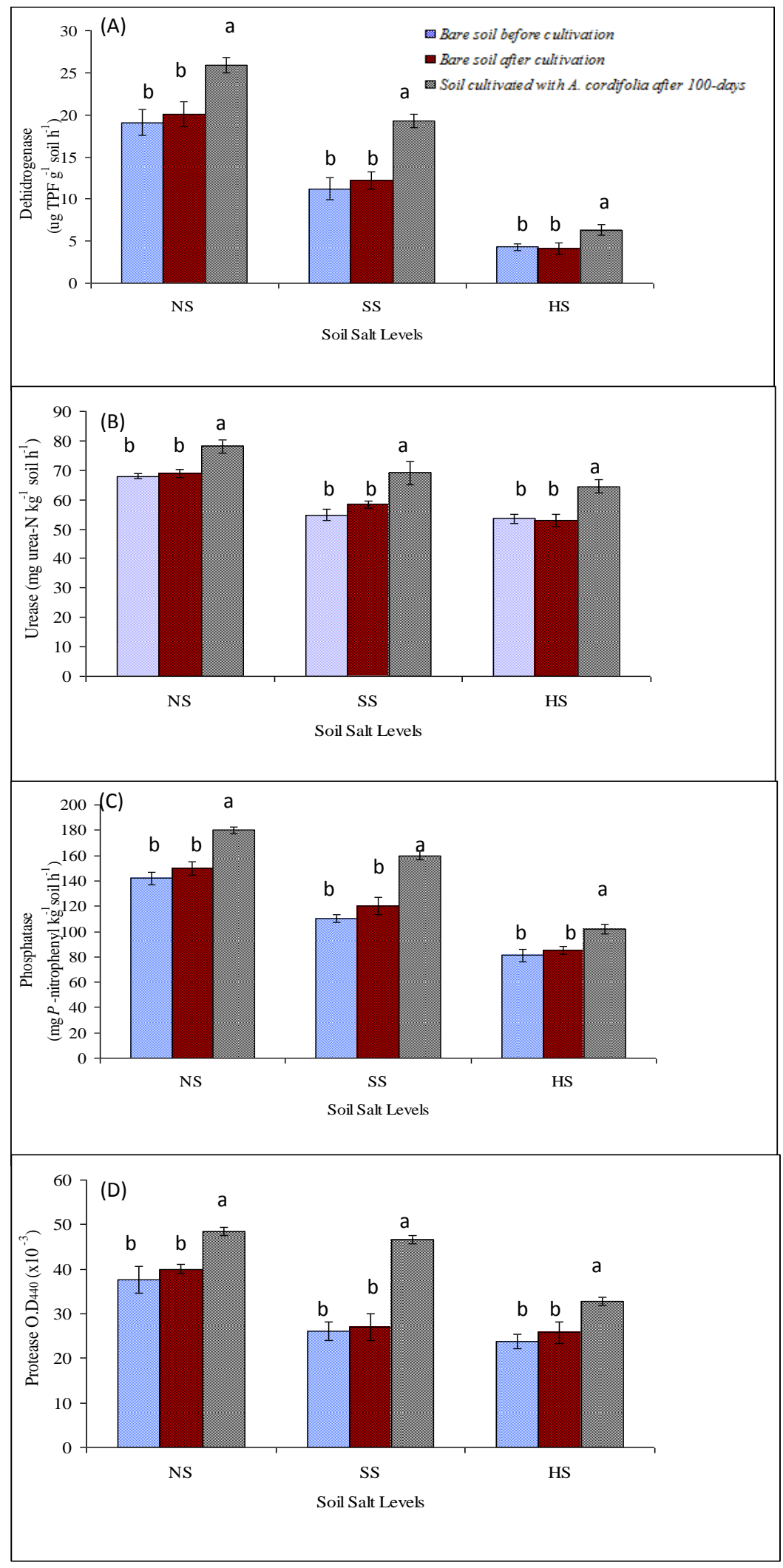

Figure 6. A) The soil dehydrogenase; B) urease; C) phosphatase; and D) protease values before and after cultivation with A. cordifolia at three different salinity levels: non-saline (NS), slightly saline (SS), and highly saline (HS) soils. Bars with different letters indicate significant differences from one another according to Duncan's Multiple Range Test at $P \leq 0.05$ 


\section{Discussion}

This study assessed the capacity of A. cordifolia to withstand salt stress. Phytoremediation and production potentials (biomass production and ion uptake) of $A$. cordifolia was evaluated at three different salinity levels in a 100-day pot experiment under controlled greenhouse conditions. Measurement was made in terms of growth, total chlorophyll, proline, malondialdehyde (MDA), mineral content, CAT and POX antioxidant enzyme changes as well as with the determination of soil $\mathrm{EC}, \mathrm{pH}, \mathrm{OM}$, ion $\left(\mathrm{Na}^{+}, \mathrm{Cl}^{-}\right)$contents and soil enzyme activities (dehydrogenase, urease, phosphatase and protease) before and after cultivation of such soils with A. cordifolia.

The results of this study showed that $A$. cordifolia plant was tolerant to both slight and high salinity. Accumulation of $\mathrm{Na}^{+}$and $\mathrm{Cl}^{-}$ions increased in the leaves at both salinity levels. Therefore, this plant would be promising in reducing the electrical conductivity (EC) of such soils. The plants displayed great tolerance to the deleterious influence of salinity by preserving the integrity of their cell membranes by their proline and enzyme levels. During the growth period, proline contents and enzyme activities increased in the leaves under increasing saline levels. The accumulation of organic osmolytes such as proline, glycine betaine, sugar, alcohols, polyamines and proteins plays a key role in maintaining the low intracellular osmotic potential of plants and in preventing the harmful effects of salinity stress (Hýskova and Ryslava, 2018; Dutta et al., 2018). In our study, lipid peroxidation (MDA), POX and CAT activities increased significantly in A. cordifolia under salt stress. Salt stress, in general, increases lipid peroxidation and induces oxidative stress in plant tissues (Kim et al., 2016; Taibi et al., 2016). However, antioxidants such as POX and CAT tend to increase in tolerant cultivars, which scavenge $\mathrm{H}_{2} \mathrm{O}_{2}$ and other reactive oxygen species (ROS). These enzymes play significant roles in preventing cellular damages. We noticed that $A$. cordifolia plants were able to increase their organic metabolites upon stress exposure. It is important to note that those parameters were measured after 100 days in saline conditions. At SS conditions, FW and DW of the plants significantly increased. It is possible that SS might exert hormonal activity on A. cordifolia plants. This might have increased the FW and DW contents of the plants. Similar findings were stated that by Cela and Munné-Bosch (2012) on A. cordifolia was able to adapt to salt stress by increasing fresh biomass production. Therefore, tolerance of this plant after relatively long time under saline conditions is quite remarkable when compared to short-time stress of glycophytes in saline conditions under salinity stress. A plant with high tolerance to salinity with high capacity to accumulate $\mathrm{Na}^{+}$and $\mathrm{Cl}^{-}$ions in their leaf or other parts including fruits is a good candidate for phytoremediation purposes (Bhuiyan et al., 2017; Karakas et al., 2017). A. cordifolia also improved the conditions of saline soils without spoiling the physical and chemical properties of such soils. Soil enzyme levels significantly increased along with the increase of OM contents and decrease in EC levels without changing $\mathrm{pH}$ balance of such soils. In most cases, changes in physical and chemical properties result in changes in $\mathrm{pH}$ levels (Miltner et al., 2012; Shrivastava and Kumar, 2015; Yang et al., 2018).

Soil enzyme activity is closely related to the carbon inputs, crop growth stages, organic matter content, microbial community structure, soil ecology, physical and chemical properties, vegetation, fertility, soil $\mathrm{pH}$, soil quality and abiotic soil environment (Jin et al., 2009; Rout et al., 2017). Microbial population and decomposition of organic matter result in increased activity of soil enzymes. For example, high urease activity was observed during the active growth of maize (Jin et al., 
2009). The present study suggests that $A$. cordifolia can be used for soil improvement in saline areas. A. cordifolia could remediate structure of soil where salinity is predicted to occur. Indeed, this species behaves similarly to those of halophytes that tolerate moderate and high doses of salt. The use of this species over halophytes has a great advantage since its vegetative life is longer than halophytes, therefore, it has significantly more time to improve soil conditions under saline threat. Its ecological competence via rapid colonization in soils and accumulation of toxic ions in over those of other species could be considered as a good remediative plant. Our next approach is to investigate other properties of this plant if it is to be used as a good companion plant with other glycophytes to improve the potential vegetative and fruiting performance under saline stress conditions. It is important to note that the performance of $A$. cordifolia plants under heavy metal polluted soils would increase the popularity and use of this plant.

\section{Conclusions}

Salinity is one of the most significant environmental problems in arid and semi-arid regions. One of the alternate ways is to use of arable lands efficiently and to include the marginal quality of areas or non-agricultural lands into agricultural areas. These areas should be remediated via physical, chemical and biological approaches. Phytoremediation, in this aspect, has many advantageous; its major advantages are the low cost and environmentally-friendly sites. In this respect use of one of salt-tolerant (halophyte) plants is one of the cost-effective methods. Although salt-tolerant plants are less affected than their non-salt tolerant counterparts to the effect of salinity, however, the generation of salt-tolerant plants is very difficult and not cost-effective as planned. Those plants might possess salt tolerance properties unlike exhibiting disease susceptibility, therefore, the generation of salt-tolerant plants might not be good solution as its own. However, this could be achieved via the use of halophyte plants if they are used for phytoremediation purposes. Phytoremediation process not only remediate the conditions of soil but also reduces the stress level on crop plants. This approach could be practiced in all soil types in differing soil salinity levels and in all plant species when co-cultivated. With this approach, much cheaper and faster improvements could be achieved. Instead of developing salt-tolerance mechanisms via expensive arrays directly on crop plants, use of phytoremediation in saline stressed soils would reduce the impact of salinity indirectly via much safer ways.

This study assessed salt tolerance capacity of the A. cordifolia in three salt levels (NS, SS and HS). Its adaptation mechanisms and performances were assessed in terms of plant growth, total chlorophyll, accumulation of osmolyte proline, MDA, and antioxidative system (POX, CAT). A. cordifolia significantly increased soil OM and soil enzymes (dehydrogenase, urease, phosphatase and protease). We suggest that cultivation of $A$. cordifolia in slightly and highly saline soils would improve the condition of soil physicochemical and soil enzymes properties in an environmentallyfriendly manner. A. cordifolia could be used in phytoremediation studies.

Acknowledgments. This study was financially supported by Harran University Scientific Research Project (HUBAP) no: 14077. We thank Dr. Murat Dikilitas for the biochemical analyses. 


\section{REFERENCES}

[1] Aebi, H. (1984): Catalase in Švitro. - Methods in Enzymology 105: 121-126.

[2] Ammari, T. G., Al-Hiary, S., Al-Dabbas, M. (2013): Reclamation of saline calcareous soils using vegetative bioremediation as a potential approach. - Archives of Agronomy and Soil Science 59: 367-375.

[3] Arnon, D. I. (1949): Copper enzymes in isolated chloroplasts, polyphenol oxidase in Beta vulgaris L. - Plant Physiology 24: 1-15.

[4] Bates, L. S., Waldren, R. P., Teare, I. D. (1973): Rapid determination of free proline for water-stress studies. - Plant Soil 39: 205-207.

[5] Bhuiyan, M. S. I., Raman, A., Hodgkins, D. S. (2017): Plants in remediating salinityaffected agricultural and landscapes. - Proceedings of the Indian National Science Academy 83: 51-66.

[6] Cela, J., Munné-Bosch, S. (2012): Acclimation to high salinity in the invasive CAM plant Aptenia cordifolia. - Plant Ecology and Diversity 5(3): 403-410.

[7] Chapman, H. D., Pratt, P. F. (1961): Methods of Analysis for Soils, Plants, and Waters. Division of Agricultural Sciences, University of California, Berkeley.

[8] Cvikrova, M., Hrubcova, M., Vagner, M., Machackova, I., Eder, J. (1994): Phenolic acids and peroxidase activity in Alfalfa (Medicago sativa) embryogenic cultures after ethephon treatment. - Plant Physiology 91(2): 226-233.

[9] Dikilitas, M. (2003): Effect of Salinity and Its Interactions with Verticillium Albo-Atrum on the Disease Development in Tomato (Lycopersicon Esculentum Mill.) and Lucerne (Medicago Sativa \& M. Media) Plants. - University of Wales, Swansea.

[10] Dutta, T., Neelapu, N.R.R., Wani, S. H., Challa, S. (2018): Compatible Solute Engineering of Crop Plants for Improved Tolerance toward Abiotic Stresses. - In: Wani, S. H. (ed.) Biochemical, Physiological and Molecular Avenues for Combating Abiotic Stress Tolerance in Plants. Elsevier, Amsterdam.

[11] FAO (1974): The Euphrates Pilot Irrigation Project. Methods of Soil Analysis, Gadeb Soil Laboratory (A Laboratory Manual). - FAO, Rome.

[12] FAO (2016): Food and Agriculture: Key to Achieving the 2030, Agenda for Sustainable Development. - Food and Agriculture Organization of the United Nations, Rome, 23, I5499, http://www.fao.org/3/a-i5499e.

[13] Flowers, T. J., Colmer, T. D. (2015): Plant salt tolerance: adaptations in halophytes. Annals of Botany 115: 327-331.

[14] Gill, S. S., Tuteja, N. (2010): Reactive oxygen species and antioxidant machinery in abiotic stress tolerance in crop plants. - Plant Physiology and Biochemistry 48: 909-930.

[15] Girard, C., Michaud, D. (2002): Direct monitoring of extracellular protease activities in microbial cultures. - Analytical Biochemistry 308(2): 388-391.

[16] Grigore, M. N., Ivanescu, L., Toma, C. (2014): Halophyte Definitions and Classifications. - In: Grigore, M. N., Ivanescu, L., Toma, C. (eds.) An Integrative Anatomical Study. Springer, New York.

[17] Guan, S. Y. (1986): Soil Enzymes and Their Research Methods. - Agricultural Scientech Press, Beijing, pp. 273-339.

[18] Gupta, B., Huang, B. (2014): Mechanism of salinity tolerance in plants: physiological, biochemical, and molecular characterization. - International Journal of Genomics. http://dx.doi.org/10.1155/2014/701596.

[19] Herppich, W. B., Peckmann, K. (1997): Responses of gas exchange, photosynthesis, nocturnal acid accumulation and water relations of Aptenia cordifolia to short-term drought and rewatering. - Journal of Plant Physiology 150: 467-474.

[20] Hossain, M. D., Inafuku, M., Iwasaki, H., Taira, N., Mostofa, M. G., Oku, H. (2017): Differential enzymatic defense mechanisms in leaves and root of two true mangrove species under long-term salt stress. - Aquatic Botany 142: 32-40. 
[21] Hýskova, V., Ryslava, H. (2018): Hyperosmotic versus hypoosmotic stress in plants. Biochemistry and Analytical Biochemistry 7(1): 170.

[22] Jin, K., Sleutel, S., Buchan, D., De Neve, S., Cai, D., Gabriels, D., Jin, J. (2009): Changes of soil enzyme activities under different tillage practices in the Chinese Loess Plateau. Soil and Tillage Research 104(1): 115-120.

[23] Johnson, C. M., Ulrich, A. (1959): II. Analytical methods for use in plant analysis. - Calif Agric Exp Stat Bull 766.

[24] Kacar, B., Inal, A. (2008): Plant Analysis. - Nobel Publication and Distribution, Ankara.

[25] Karakas, S. (2013): Development of tomato growing in soil differing in salt levels and effects of companion plants on same physiological parameters and soil remediation. $\mathrm{PhD}$, University of Harran, Sanlıurfa.

[26] Karakas, S., Cullu, M. A., Kaya, C., Dikilitas, M. (2016): Halophytic companion plants improve growth and physiological parameters of tomato plants grown under salinity. Pakistan Journal of Botany 48: 21-28.

[27] Karakas, S., Cullu, M. A., Dikilitas, M. (2017): Comparison of two halophyte species (Salsola soda and Portulaca oleracea) for salt removal potential under different soil salinity conditions. - Turkish Journal of Agriculture and Forestry 41: 183-190.

[28] Kaushal, J., Bhasin, S. K., and Bhardwaj, P. (2015): Phytoremediation: a review focusing on phytoremediation mechanisms. - International Journal of Research 5: 1-9.

[29] Kim, J., Liu, Y., Zhang, X., Zhao, B., Childs, K. (2016): Analysis of salt-induced physiological and proline changes in 46 switchgrass (Panicum virgatum) lines indicates multiple responses modes. - Plant Physiology Biochemistry 105: 203-212.

[30] Miltner, A., Bombach, P., Schmidt-Brücken, B., Kästner, M. (2012): SOM genesis: microbial biomass as a significant source. - Biogeochemistry 111: 41-55.

[31] Negrao, S., Schmockel, S. M., Tester, M. (2017): Evaluating physiological responses of plants to salinity stress. - Annals of Botany 119: 1-11.

[32] Panta, S., Doyle, R., Hardie, M., Lane, P., Flowers, T., Haros, G., Shabala, S. (2018): Can highly saline irrigation water improve sodicity and alkalinity in sodic clayey subsoils? Journal of Soils and Sediments. DOI: 10.1007/s11368-018-1986-3.

[33] Rout, P. P., Chandrasekaran, N., Padhan, D. (2017): Soil enzyme activity as influenced by seasonal rainfall and crop growth stages under long-term fertilization and intensive cropping with hybrid maize. - International Journal of Plant and Soil Science. 18(2): 1-9.

[34] Sairam, R. K., Sexena, D. (2000): Oxidative stress and antioxidants in wheat genotypes: a possible mechanism of water stress tolerance. - Journal of Agronomy and Crop Science 184: 55-61.

[35] Shrivastava, P., Kumar, R. (2015): Soil salinity: a serious environmental issue and plant growth promoting bacteria as one of the tools for its alleviation. - Saudi Journal of Biological Sciences 22: 123-131.

[36] Slama, I., Abdelly, C., Bouchereau, A., Flowers, T., Savoure, A. (2015): Diversity, distribution and roles of osmoprotective compounds accumulated in halophytes under abiotic stress. - Annals of Botany 115: 433-447.

[37] Soil Conservation Service (1972): Soil Survey Laboratory Methods and Procedures for Collecting Soil Samples. - Soil Survey Invest Rep No. 1. US Gov Print Office, Washington, DC.

[38] Tabatabai, M. A. (1994): Soil Enzymes. - In: Weaver, W., Angel, J. S., Bottomley, P. S. (eds.) Methods of Soil Analysis. Part 2. Microbiological and Biochemical Properties. SSSA Book Series 5, Soil Science Society of America, Madison, WI.

[39] Taibi, K., Taibi, F., Abderrahim, L. A., Ennajah, A., Belkhodja, M., Mulet, J. M. (2016): Effect of salt stress on growth, chlorophyll content, lipid peroxidation and antioxidant defense systems in Phaseolus vulgaris L. - South African Journal of Botany 105: 306312.

[40] Thomas, G. W. (1996): Soil pH and Soil Acidity. - In: Sparks, D. L. (ed.) Methods of Soil Analysis: Part 3. Chemical Methods. Soil Science Society of America, Madison, WI. 
[41] Tripodi, K. E. J., Modesta, F. E. (2003): Purification and characterization of an NADdependent malate dehydrogenase from leaves of the crassulacean acid metabolism plant Aptenia cordifolia. - Plant Physiology and Biochemistry 41: 97-105.

[42] Walkley, A. (1947): A critical examination of a rapid method for determining organic carbon in soils: effects of variations in digestion conditions and of inorganic soil constituents. - Soil Sciences 37: 29-38.

[43] Yang, M., Yang, D., Yu, X (2018): Soil microbial communities and enzyme activities in sea-buckthorn (Hippophae rhamnoides) plantation at different ages. - PLoS One 13(1).

[44] Yuan, B. C., Li, Z. Z., Liu, H., Gao, M., Zhang, Y. Y. (2007): Microbial biomass and activity in salt-affected soils under arid conditions. - Applied Soil Ecology 35: 319-328. 